\title{
The Normative Dimension of the Pastoral Formation of Seminarians
}

This article presents the Church's vision for the pastoral formation of candidates for the priesthood. Specifically, the concept for formation contained in the new The Gift of the Priestly Vocation: Ratio Fundamentalis Institutionis Sacerdotalis (2016) will be presented in light of the teachings of the Second Vatican Council and post-conciliar popes, including St. John Paul II, Benedict XVI, and Francis. Local churches, including those in Poland, can adapt and implement this concept of pastoral formation in major seminaries. This analysis will focus on initial pastoral formation, the nature and aims of pastoral formation, and the study of pastoral theology and pastoral practices in preparation for the priesthood.

Key words: clerical formation, seminary formation, priestly formation, pastoral formation, seminary.

Documents from the Second Vatican Council as well as post-conciliar teaching present a model for the pastoral formation of candidates for the priesthood. Among these documents, Pope John Paul II's Apostolic Exhortation Pastores Dabo Vobis and The Decree on the Priestly Training: Optatam Totius are particularly significant because they provide the foundation for the Church's concept of pastoral formation of the clergy. This document is not only the result of the synod of bishops' work dedicated to the issue of preparing men for the priesthood, but also the continuation and development of the ideas and thought that arose during the Second Vatican Council. It contains a complete concept of the multifaceted formation that takes place before a man is ordained, and it presents the fundamental ideas pertaining to the 
formation of permanent presbyters. Popes Benedict XVI and Francis have both frequently pointed out the significance of the role of priestly formation and stressed the importance of its various aspects. The Congregation for the Clergy outlined the new model of priestly and pastoral formation in the document Ratio Fundamentalis Institutionis Sacerdotalis.

\section{Pastoral Formation According to St. John Paul II}

According to St. John Paul II in Pastores Dabo Vobis, "[t]he whole formation imparted to candidates for the priesthood aims at preparing them to enter into communion with the charity of Christ the good shepherd. Hence their formation in its different aspects must have a fundamentally pastoral character." ${ }^{1}$ Pope John Paul II refers to Pope Paul VI's conciliar Decree on Priestly Training: Optatam Totius, which states the following regarding preparation of future priests in major seminaries: "Here the entire training of the students should be oriented to the formation of true shepherds of souls after the model of our Lord Jesus Christ, teacher, priest and shepherd."2 The teachings of the Church reveal that pastoral formation plays a crucial role in preparing candidates for the priesthood and an important role in all other aspects of formation. In a certain way, all other aspects of formation are subject to pastoral formation. This is what the Church in Poland means when it states that pastoral formation is the "aim and keystone of formation." 3

Both the Second Vatican Council and St. John Paul II emphasized the intrinsic and profound connection between each of the particular aspects of priestly formation. Specifically, they both point out that all of priestly formation before ordination is pastorally oriented. According to St. John Paul II, "This pastoral aim ensures that the human, spiritual and intellectual formation has certain precise content and characteristics; it also unifies and gives specificity to the whole formation of future priests." 4

Human formation is the foundation of preparation for the priesthood. ${ }^{5}$ The teachings of the Church assert the need to form candidates

1 John Paul II, Pastores Dabo Vobis 57. Hereafter abbreviated as PDV.

2 Paul VI, Optatam Totius 4. Hereafter abbreviated as OT.

3 Zasady formacji kapłańskiej w Polsce, Częstochowa: Kuria Metropolitalna i Tygodnik Katolicki "Niedziela," 1999, pg. 112.

Ibid, 43. 
for the priesthood so that their personalities can mature. The aim of this endeavor is to ensure that seminary students are formed according to the example of Jesus Christ, who became man. For this reason, young people should contemplate the humanity of Christ, which is revealed primarily in his attitude towards others. ${ }^{6}$ In this way, as St. John Paul II emphasized, human formation is particularly important with regard to those to whom priests are sent: "In order that his ministry may be humanly as credible and acceptable as possible, it is important that the priest should mold his human personality in such a way that it becomes a bridge and not an obstacle for others in their meeting with Jesus Christ the Redeemer of humanity."

Human formation is important in seminary education to both form mature personalities and human qualities in the students for their own good and because: "Future priests [... need] to be balanced people, strong and free, capable of bearing the weight of pastoral responsibilities." 8 The teachings of the Church point out that it is necessary to form such qualities as: integrity, love of truth, reliability, respect for others, a sense of justice, fidelity to one's word, consistent actions, an ability to show compassion, and the ability to make balanced judgments. Within the context of future pastoral ministry, the Church indicates that it is necessary for candidates for the priesthood to demonstrate emotional maturity as well as an acceptance of celibacy as a gift that enables men to offer themselves in unselfish service to others. Priestly formation should also seek to help candidates to be able to establish true friendships, exercise freedom, and properly form their consciences not only for their own present good, but also so that their ministry can be both authentic and fruitful in the future. ${ }^{9}$

Spiritual formation of candidates for the priesthood is based on the religiosity that is common to all people. Christians strive to know and be united with God. Christian spiritual formation, therefore, strives to foster filial devotion to God the Father, to establish and deepen ones relationship with His Son Jesus Christ, and to submit oneself to the action of the Holy Spirit. "And just as for all the faithful spiritual formation is central and unifies their being and living as Christians, that is, as new creatures in Christ who walk in the Spirit, so too for every

$6 \quad$ See Benedict XVI, Letter to Priests (06.16.2009), http://w2.vatican.va/content/ benedict-xvi/en/letters/2009/documents/hf_ben-xvi_let_20090616_anno-sacerdotale.html.

$7 \quad$ PDV 43

$8 \quad$ PDV 43. 
Pastoral theology

priest his spiritual formation is the core which unifies and gives life to his being a priest and his acting as a priest." 10

The spiritual formation of candidates for the priesthood is different from the spiritual formation of religious and the laity. ${ }^{11}$ The aim of the spiritual formation of seminarians is to develop in them an ability to give themselves as a free and generous gift to others. Priests are called to reveal and show Christ the Good Shepherd who gave Himself to others. "From this point of view, spiritual formation has and should develop its own inherent pastoral and charitable dimension." ${ }^{12,13}$

Spiritual formation is pastoral and, therefore, strives to form in seminarians an attitude of pastoral charity of which Jesus Christ the Good Shepherd is the perfect example. ${ }^{14}$ The essence of pastoral formation is the way in which the Holy Spirit leads the person called to Jesus' love; ${ }^{15}$ for, it is Christ Himself who forms the candidates for ordination so that they will be able to carry out the service entrusted to them. Christ also pours out His love upon them and, by it, strengthens and guides them. "In this sense preparation for the priesthood must necessarily involve a proper training in charity and particularly in the preferential love for the 'poor' in whom our faith discovers Jesus (cf. Mt. 25:40) and a merciful love for sinners." 16

Moreover, formators should educate candidates on celibacy from a pastoral perspective. To this end, priestly celibacy should be considered "a value that is profoundly connected with ordination, whereby a man takes on the likeness of Jesus Christ, the good shepherd and spouse of the Church, and therefore as a choice of greater and

$10 \quad$ PVD 45.

11 See Benedict XVI, Address by the Holy Father: Meeting with the Clergy, (Warsaw, 05.25.2006), 6-7.http://w2.vatican.va/content/benedict-xvi/en/speeches/2006/may/ documents/hf_ben-xvi_spe_20060525_poland-clergy.html. PVD 49.

13 See D. Lipiec, Formacja pastoralna prezbitera, "Studia Teologiczne" Bialystok - Drohiczyn - Lomza" 23:2005, pgs. 151-155.

14 See R. Kamiński, Pastoralna formacja, in Leksykon teologii pastoralnej, (eds.) R. Kamiński, W. Przygoda, M. Fiałkowski, Lublin: TN KUL 2006, pg. 597.

15 See Francis, Address of the Holy Father: Meeting with Clergy, Religious and Seminarians (El Quinche 07.08.2015), nr 7-8, https://w2.vatican.va/content/francesco/ en/speeches/2015/july/documents/papa-francesco_20150708_ecuador-religiosi. html.

16 PVD 49; See Francis, Spiritual Retreat Given by His Holiness Pope Francis on the Occasion of the Jubilee for Priests (Rome, 06.02.2016), https://w2.vatican.va/ content/francesco/en/speeches/2016/june/documents/papa-francesco_20160602_ giubileo-sacerdoti-prima-meditazione.html (05.15.2018). 
undivided love for Christ and his Church, as a full and joyful availability in his heart for the pastoral ministry." 17 Similarly, education in a life of obedience and poverty should be perceived as an aspect of formation that aims not only to shape the personal holiness of the one who is called, but also to enable the called to engage in pastoral ministry. The Second Vatican Council taught that "students should understand most clearly that they are not destined for domination or for honors but are given over totally to the service of God and to Pastoral the pastoral ministry. With a particular concern should they be so formed in priestly obedience, in a simple way of life and in the spirit of self-denial." 18

Just as human formation and spiritual formation have a pastoral quality, so too does " $\mathrm{t}]$ ]he intellectual formation of candidates for the priesthood find its specific justification in the very nature of the ordained ministry." 19 According to St. John Paul II, intellectual formation is closely connected to pastoral formation, and

the challenge of the 'new evangelization' to which our Lord is calling the Church on the threshold of the third millennium shows just how important this formation is. [...C]andidates for the priesthood and priests [should] have diligent care of the quality of their intellectual formation in their education and pastoral activity. For the salvation of their brothers and sisters they should seek an ever deeper knowledge of the divine mysteries. ${ }^{20}$

From a pastoral point of view, not only theological and philosophical study is necessary in intellectual formation, but so too is knowledge of the social sciences. Even more, seminary formation should ensure that an integrated and comprehensive theological education is provided in accordance with the Teaching Office of the Church and

oppose firmly the tendency to play down the seriousness of studies and the commitment to them. [...] The very situation of the Church today demands increasingly that teachers be truly able to face the complexity

$17 \quad$ PVD 50.

18 Paul VI, Optatam Toitius 9. Por. Francis, Address of His Holiness Pope Francis to the $36^{\text {th }}$ General Congregation of the Society of Jesus (Rome, 10.24.2016), 11, https:/w2.vatican.va/content/francesco/en/speeches/2016/october/documents/ papa-francesco_20161024_visita-compagnia-gesu.html. PVD 51.

$20 \quad$ PVD 51; Por. Francis, Address of His Holiness Pope Francis to Participants in the International Conference on Pastoral Work for Vocations Sponsored by the Congregation for the Clergy (Rome 10.21.2016), 11, https://w2.vatican.va/content/ francesco/en/speeches/2016/october/documents/papa-francesco_20161021_pastorale-vocazionale.html. 
Pastoral theology

of the times and that they be in a position to face competently, with clarity and deep reasoning, the questions about meaning which are put by the people of today... ${ }^{21}$

As the teachings of the Church reveal, pastoral formation cannot be treated as an addition or supplementation to the human, spiritual, and intellectual formation of candidates for the priesthood. The scope of pastoral formation cannot be restricted and assume the "leading role" of all formation. As St. John Paul II taught,

pastoral formation certainly cannot be reduced to a mere apprenticeship, aiming to make the candidate familiar with some pastoral techniques. The seminary which educates must seek really and truly to initiate the candidate into the sensitivity of being a shepherd, in the conscious and mature assumption of his responsibilities, in the interior habit of evaluating problems and establishing priorities and looking for solutions on the basis of honest motivations of faith and according to the theological demands inherent in pastoral work. ${ }^{22}$

\section{Pastoral Formation According to the New Ratio Fundamentalis Institutionis Sacerdotalis}

The new The Gift of the Priestly Vocation: Ratio Fundamentalis Institutionis Sacerdotalis (abbreviated hereafter as Ratio Fundamentalis) presents pastoral formation from two perspectives. First, it depicts pastoral formation as a temporary stage of preparation before ordination to the priesthood. Then, the document presents pastoral formation as one aspect of priestly formation that correlates with other aspects of such formation. Seminary formation is basic formation, while formation beyond seminary formation is considered ongoing formation. Initial formation and permanent formation are collectively referred to as integrated formation.

\section{Initial Pastoral Formation}

In the new Ratio Fundamentalis, seminary (initial) formation is divided into the following four stages: the propaedeutic stage, the stage of philosophical studies or discipleship stage, the stage of theological

\footnotetext{
21 PVD 56; Por. R. Kamiński, Formacja pastoralna, EK vol. 5, col. 391-392.

22 PVD 58; Por. D. Lipiec, Blaski i cienie formacji pastoralnej w polskich seminariach duchownych, in Blaski i cienie formacji pastoralnej $w$ polskich seminariach duchownych w kontekście wyzwań Nowej Ewangelizacji, (ed.) P. Matuszak, Niepokalanów: Wydawnictwo Ojców Franciszkanów 2016, pgs. 9-15.
} 
studies or the configuration stages, and the pastoral stage or stage of vocational synthesis. In the document, these stages are described in detail, but the content related to pastoral formation is presented only in the final stage of preparation for ordination. The document states, however, that all dimensions of seminary formation occur concurrently in the preparation process, even though certain aspects are emphasized during specific stages.

The new Ratio Fundamentalis discusses the issue of pastoral forma- theology tion and presents the pastoral stage known as vocational synthesis. The document states that the "pastoral stage, or vocational synthesis, is the time from leaving the Seminary until the subsequent priestly ordination, which obviously is brought about by conferral of the diaconate. This stage has a twofold purpose: on the one hand it is about being inducted into the pastoral life, with a gradual assumption of responsibilities in a spirit of service; on the other hand it is about making a suitable preparation, with the help of a specific accompaniment, in view of the priesthood. During this stage, the candidate is asked to declare freely, consciously, and definitively his intention to be a priest, having received diaconal ordination." 23 This stage of pastoral formation takes place after philosophical and theological studies and is a type of pastoral training. The document confirms this idea, stating,

This stage will normally take place outside of the Seminary building, at least for a significant period of time. This period, which will normally be lived in the service of a community, can make a great impact on the personality of the candidate. Consequently, it is recommended that the Pastor [parochus], or whichever person is responsible for the pastoral setting that receives the seminarian, should be aware of the formative task entrusted to him, and should accompany him in his gradual entry to pastoral ministry. ${ }^{24}$

This model of pastoral formation as well as all of priestly formation resemble the models that the Church in Germany follows, where pastoral formation is more intense after the candidates have finished their theological studies with lay students. According to Ratio Fundamentalis, the different Conferences of Bishops should determine what the final stage of pastoral formation looks like according to their own experiences and based on local determinants and needs.

The duration of the pastoral stage is not strictly determined, as Ratio Fundamentalis clearly indicates: "the duration of this stage of formation varies, and depends on the maturity and suitability of the

$23 \quad$ Ibid, 74 .

$24 \quad$ Ibid, 75 . 
Pastoral theology

candidate. Nonetheless, at least the times canonically established between the reception of the diaconate and of the presbyterate must be respected." "25 Consequently, pastoral formation and all of priestly formation largely depend on individual dioceses. The Ordinary is responsible for pastoral preparation. He, in agreement with the Rector of the Seminary, chooses the community in which this stage of formation takes place. The criteria for choosing a community are as follows: the requirements of a local presbytery, the existing opportunities for formation, as well as the competence and responsibility of a pastor or superior of a community in which this stage of formation is to take place. ${ }^{26}$

\section{The Nature and Aims of Pastoral Formation}

Following the Apostolic Exhortation Pastores Dabo Vobis, Ratio Fundamentalis lists
four dimensions that interact simultaneously in the iter of formation and in the life of ordained ministers: the human dimension, which represents 'the necessary and dynamic foundation' of all priestly life; the spiritual dimension, which helps to shape the quality of priestly ministry; the intellectual dimension, which provides the rational tools needed in order to understand the values that belong to being a pas- tor, to make them incarnate in daily life, and to transmit the content of the faith appropriately; the pastoral dimension, which makes possible a responsible and fruitful ecclesial service. ${ }^{27}$

Following the conciliar Decree on Priestly Training: Optatam Totius, Ratio Fundamentalis indicates that the "entire process of formation in preparation for priestly ministry, in fact, has as its aim the preparation of seminarians 'to enter into communion with the charity of Christ the Good Shepherd.""28 The new Ratio Fundamentalis points out the integral character of priestly formation. In this case, the features of integrality refer to the aspects (dimensions) of formation. According to the document,

[t]he concept of integral formation is of the greatest importance, since it is the whole person, with all that he is and all that he possesses, who will be at the Lord's service in the Christian community. The one called by God is an 'integral subject,' namely someone who has been

\begin{tabular}{ll}
\hline 25 & Ibid, 76. \\
26 & Ibid, 75-76. \\
27 & Ibid, 89. \\
28 & Ibid.
\end{tabular}


previously chosen to attain a sound interior life, without divisions or contradictions. It is necessary to adopt an integrated pedagogical model [... that ensures] a proper balance between the different dimension of formation..$^{29}$

Unlike Pastores Dabo Vobis, Ratio Fundamentalis does not directly refer to the pastoral dimension of formation when describing the human, spiritual, and intellectual dimensions of formation. Instead, the document discusses the individual dimensions of formation separately Pastoral and does not emphasize their relationship to other dimensions of formation. Since the purpose of priestly formation is to form men into shepherds according to the example of Jesus Christ the Good Shepherd, "priestly formation must be permeated by a pastoral spirit." 30

The Congregation of the Clergy's new document points out numerous aspects that should be worked on in the candidates for ordination through pastoral formation. The first feature is the ability to cooperate with the faithful and to guide communities of believers. The document emphasizes that the priest's ability to collaborate with the laity, members of consecrated life, and permanent deacons is to know the specifics about their vocations as well as their respective place and role in the Church.

The next feature that clerics must develop during seminary formation is to become "experts in the art of pastoral discernment, that is to say, able to listen deeply to real situations and capable of good judgment in making choices and decisions." 31 The document understands this art as an ability to listen, to have empathy for those whom priests encounter in their ministry, and an ability to accompany them. This involves not so much professional preparation, but rather an ability to learn to "exercise his ministry with a disposition of serene openness and attentive accompaniment in all situations, even those that are the most complex, showing the beauty and demands of the Gospel truth, without falling into legalistic or rigorist obsessions." ${ }^{32}$ A similar attitude must be instilled in candidates with regard to those who do not believe or have distanced themselves from the Church. For this reason, it is

Ibid, 92. See Francis, Message of His Holiness Pope Francis On the Occasion of the 53 ${ }^{\text {rd }}$ World Day of Prayer for Vocations: The Church, Mother of Vocations, Vatican City, 2015, 12, https://w2.vatican.va/content/francesco/en/messages/vocations/documents/papa-francesco_20151129_53-messaggio-giornata-mondialevocazioni.html.

Ibid, 120.

Ibid. 
important to form candidates to be sensitive to and able to seek out and take advantage of opportunities to encounter such individuals. In general, Ratio Fundamentalis indicates that candidates for ordination need to develop a "pastoral style" that stems from their union with Christ the Good Shepherd.

Pastoral theology

\section{The Study of Pastoral Theology and Practice}

The new Ratio Fundamentalis conveys that those being formed for priestly ordination need to engage in theological and pastoral study. Besides the apostolic activities in which seminarians are involved, study is considered the basis of solid pastoral formation. Theological studies in biblical teaching, liturgy, dogmatic theology, moral theology, and theology of spirituality are elements of intellectual formation. While the document does not formulate its own definitions or understandings of pastoral theology, it cites the following descriptions of these disciplines noted in Pastores Dabo Vobis:

[Pastoral theology] is a scientific reflection on the Church as she is built up daily, by the power of the Spirit, in history. [...] Pastoral theology is not just an art. Nor is it a set of exhortations, experiences and methods. It is theological in its own right, because it receives from the faith the principles and criteria for the pastoral action of the Church in history, a Church that each day 'begets' the Church herself [...] Among these principles and criteria, one that is specially important is that of the evangelical discernment of the socio-cultural and ecclesial situation in which the particular pastoral action has to be carried out. ${ }^{33}$

Ratio Fundamentalis describes neither the characteristics of pastoral theology nor its role in the formation process as it does with other scientific disciplines. In another place, the document does point out, however, that pastoral theology "will benefit, where necessary, from the useful contribution of the human sciences, especially of psychology, pedagogy, and sociology." 34

In addition to pastoral theology, Ratio Fundamentalis recommends that lectures be given on topics that pertain directly to priestly service, including: "ars celebrandi," homiletics, hearing confessions, popular piety and devotion, hagiography, administering the Church's material goods, sacred art, means of social communication, and foreign languages. Each country's Ratio Studiorum can and should include

\footnotetext{
33 Ibid, 170.

$34 \quad$ Ibid, 122.
} 
other topics that are necessary for priests to effectively provide pastoral ministry in their local churches.

While Ratio Fundamentalis does not explicitly mention lectures or seminars in pastoral theology, it does indirectly indicate the need for this type of activity: "seminarians should be introduced to the study of various pastoral questions by a scientific method so that they can better comprehend the intimate connections between life, piety and the knowledge attained in lectures." ${ }^{35}$ Didactic methods that "promote dialogue and engagement among seminarians, and between seminarians and their professors, through an ability to sustain logical and rational discussion" should also be used..$^{36}$

That which Ratio Fundamentalis calls "exercises" is essential pastoral practice. The Holy See's document emphasizes the importance of pastoral practice:

According to the prudent judgment of the Bishop, [seminarians] should be introduced to some apostolic experiences throughout the period of formation, in the most suitable times and ways, making particular use of days or periods not scheduled for academic classes. These are indispensable for the integral formation of the candidate, and should be geared to the age of the seminarian and to the various abilities of individuals. Each Seminary, in coordination with other diocesan institutions and in close contact with them, should set out what will be expected of the pastoral placement, arranging it over the year and in such a way that it does not clash with the other demands of formation. ${ }^{37}$

Ratio Fundamentalis follows the Church's previous teaching and indicates the environments in which pastoral practice should take place. The primary location that pastoral practice should occur is in a parish, since this is where both ordinary and sometimes extraordinary forms of pastoral ministry occur. The document also indicates that pastoral practice can also take place among people and groups of people to whom clerics should be directed: children, youth, the elderly, the sick, the disabled, the imprisoned, the lonely, the poor, and migrants. In addition, seminarians need to be involved in providing pastoral care to families. ${ }^{38}$ Certain apostolic activities in which candidates for ordination become involved should be overseen by competent

\footnotetext{
$35 \quad$ Ibid, $187 \mathrm{e}$.

36 Ibid, $186 \mathrm{~d}$.

37 Ibid, 124.
}

38 See M. Olszewski, Formacja pastoralna, in W nurcie zagadnień pastoralnych, (ed.) M. Olszewski, Bialystok: Kuria Metropolitalna Białostocka 2002, pgs. 103-104. 
individuals who are responsible for the Church, including clerics, consecrated individuals, and the laity. ${ }^{39}$ The Rector of the Seminary is responsible for organizing the seminarians' pastoral practice. To this end, the Rector should do so in agreement with the Ordinary and should take into account the specific needs of the particular parish, while simultaneously opening the candidates up to the needs of the universal Church. ${ }^{40}$

\section{Conclusion}

The Congregation for the Clergy's new document The Gift of the Priestly Vocation: Ratio Fundamentalis Institutionis Sacerdotalis is based on the conciliar concept of priestly formation. Consequently, it simultaneously points out the "signs of the times" and the necessity to make certain changes and update the process of pastoral preparation to meet the current conditions of the lives of contemporary Christians and the candidates for the priesthood themselves. To this end, the document takes into account the present challenges that socio-religious changes have brought about and which the clergy must face. Ratio Fundamentalis' indications must be applied to the pastoral formation of clerics in the Church in Poland, and many of its different proposals need to be applied in the Polish Ratio Studiorum. Introducing practice and exercises in pastoral theology so that candidates for the priesthood can better acquire the skills necessary for pastoral ministry would better prepare the candidates for their ministry as priests in the Church.

\section{FORMACJA PASTORALNA KLERYKÓW W WYMIARZE NORMATYWNYM}

W artykule przedstawiona została wizja formacji pastoralnej kandydatów do kapłaństwa nakreślona w nauczaniu Kościoła współczesnego. Na tle nauczania Soboru Watykańskiego II oraz papieży doby posoborowej, przede wszystkim św. Jana Pawła II i wskazań Benedykta XVI i Franciszka, została przedstawiona koncepcja zawarta w nowym Ratio fundamentalis institutionis sacerdotalis. Koncepcja ta zostanie zaadaptowana przez Kościoły lokalne, w tym także Kościół w Polsce i skierowana do realizacji w wyższych seminariach duchownych.

39 Ratio Fundamentalis Institutionis Sacerdotalis, 124. 
W analizach zawartych w artykule uwaga została zwrócona na formację pastoralną jako etap formacji początkowej, naturę i cele formacji pastoralnej oraz na studium teologii pastoralnej i praktyki duszpasterskie w programie przygotowania do kapłaństwa.

Słowa kluczowe: formacja kleryków, formacja seminaryjna, formacja do kapłaństwa, formacja kapłańska, formacja pastoralna, seminarium duchowne.

\section{Bibliography:}

1. Benedict XVI, Address by the Holy Father: Meeting with the Clergy, (Warsaw, 05.25.2006), 6-7. http:/w2.vatican.va/content/benedict-xvi/en/speeches/2006/may/documents/hf_ben-xvi_spe_20060525_poland-clergy.html.

2. Benedict XVI, Letter to Priests (06.16.2009), http://w2.vatican.va/content/ benedict-xvi/en/letters/2009/documents/hf_ben-xvi_let_20090616_annosacerdotale.html.

3. Congregation for the Clergy, The Gift of the Priestly Vocation: Ratio Fundamentalis Institutionis Sacerdotalis, Vatican City 2016, http://www.clerus. va/content/dam/clerus/Ratio\%20Fundamentalis/The\%20Gift\%20of\%20 the\%20Priestly\%20Vocation.pdf (Accessed 03.01.2018).

4. John Paul II, Apostolic Exhortation: Pastores Dabo Vobis, Rome 1992.

5. Francis, Address of the Holy Father: Meeting with Clergy, Religious and Seminarians (El Quinche, 07.08.2015), 7-8, https://w2.vatican.va/content/ francesco/en/speeches/2015/july/documents/papa-francesco_20150708_ ecuador-religiosi.html.

6. Francis, Address of His Holiness Pope Francis to the $36^{\text {th }}$ General Congregation of the Society of Jesus (Rome, 10.24.2016), 11, https://w2.vatican.va/ content/francesco/en/speeches/2016/october/documents/papa-francesco_20161024_visita-compagnia-gesu.html.

7. Francis, Address of His Holiness Pope Francis to Participants in the International Conference on Pastoral Work for Vocations Sponsored by the Congregation for the Clergy (Rome 10.21.2016), 11, https://w2.vatican.va/ content/francesco/en/speeches/2016/october/documents/papa-francesco_20161021_pastorale-vocazionale.html.

8. Francis, Message of His Holiness Pope Francis On the Occasion of the $53^{\text {rd }}$ World Day of Prayer for Vocations: The Church, Mother of Vocations, Vatican City, 2015, 12, https://w2.vatican.va/content/francesco/en/messages/ vocations/documents/papa-francesco_20151129_53-messaggio-giornatamondiale-vocazioni.html.

9. Francis, Spiritual Retreat Given by His Holiness Pope Francis on the Occasion of the Jubilee for Priests (Rome, 06.02.2016), https://w2.vatican. va/content/francesco/en/speeches/2016/june/documents/papa-francesco_20160602_giubileo-sacerdoti-prima-meditazione.html (Accessed: 05.15.2018).

10. Kamiński R., Formacja pastoralna, EK Vol. 5, col. 391-392. 
11. Kamiński R., "Pastoralna formacja," in Leksykon teologii pastoralnej, (eds.) R. Kamiński, W. Przygoda, M. Fiałkowski, Lublin: TN KUL 2006, pgs. 596-599.

12. Lipiec D., Blaski i cienie formacji pastoralnej $w$ polskich seminariach duchownych, in Blaski i cienie formacji pastoralnej w polskich seminariach duchownych w kontekście wyzwań Nowej Ewangelizacji, (ed.) P. Matuszak, Niepokalanow: Wydawnictwo Ojcow Franciszkanow 2016, pgs. 9-23.

Pastoral theology
13. Lipiec D., Formacja pastoralna prezbitera, "Studia Teologiczne," BialystokDrohiczyn-Lomza 23:2005, pgs. 151-164.

14. Olszewski M., Formacja pastoralna, in W nurcie zagadnień pastoralnych, (ed.) M. Olszewski, Bialystok: Kuria Metropolitalna Bialostocka 2002, pgs. 97-110.

15. Paul VI, Decree on the Life and Ministry of Priests: Presbyterorum Ordinis, Vatican City, 1965.

16. Paul VI, Decree on Priestly Training: Optatam Totius, Vatican City, 1965.

17. Zasady formacji kapłańskiej w Polsce, Czestochowa: Kuria Metropolitalna i Tygodnik Katolicki "Niedziela" 1999. 